\title{
WEDDING PROBLEMS VIA PHONE: ISLAMIC LAW PERSPECTIVE
}

\author{
Oleh: Sippah Chotban \\ E-mail: sippahchotban123@gmail.com \\ Fakultas Syariah dan Hukum UIN Alauddin Makassar
}

\begin{abstract}
Abstrak
Tulisan ini mencoba kembali mempercakapkan aspek hukum perkawinan via telp dalam perspektif hukum Islam. Oleh sebab, di tengah-tengah merebaknya wabah covid1-19, obsesi dan bahkan praktik pernikahan marak di lakakukan di mana-mana, meskipun menggunakan protokol kesehatan sebagaimana yang diaturtentukan oleh pemerintah baik yang bersifat nasional maupun daerah. Olehnya, eksistensi keberadaan perkawinan via telpon menjadi penting untuk dipercakapkan lebih lanjut dalam aspek hukum Islam; bagaimana hukum Islam melihat kedudukan hukum perkawinan via telpon.
\end{abstract}

\section{PENDAHULUAN}

Salah satu keunikan hukum Islam adalah memiliki logika maslahat yang berfungsi untuk menjawab berbagai persoalan mutakahir. Dalam pembacaan Abu Ishak Shatibi, hukum Islam pada sesungguhnya memiliki lima kontruksi tujuan diturunkan dan atau disyariatkan, yaitu (1) agama, (2) jiwa, (3) akal, (4) keturunan dan (5) harta, yang kemudian disepakati oleh ilmuwan hukum Islam lainnya. Kelima tujuan hukum Islam itu di dalam kepustakaan disebut al-maqashid al-khamsah atau al-maqashid al-shari'ah. ${ }^{1}$ Termasuk salah satu tujuan dari hukum Islam menurut Abu Ishak Shatibi tersebut adalah memelihara keturunan, tujuan tersebut dimaksudkan agar kemurnian darah dapat dijaga dan kelanjutan umat manusia dapat diteruskan. Cara untuk mewujudkan tujuan hukum Islam tersebut dapat tercapai dengan jalan perkawinan (pernikahan dalam Islam).

Selain itu, manusia diciptakan sebagai makhluk biologis yang berketurunan, agar berbeda dengan hewan, maka hubungan biologisnya diatur melalui lembaga perkawinan yang suci, sebagai media penyaluran kebutuhan biologis dan melahirkan keturunan yang terhormat, sesuai dengan harkat dan martabat kemanusiaannya, yang dikarunia hati, perasaan, dan pikiran berdasarkan keimanan dan keberagamaan. ${ }^{2}$ Rukun dan syarat menentukan suatu perbuatan hukum, terutama yang menyangkut sah atau tidaknya perbuatan tersebut dari segi hukum. Kedua kata tersebut mengandung arti yang sama dalam hal bahwa keduanya merupakan sesuatu yang harus diadakan. Dalam suatu acara perkawinan misalnya

\footnotetext{
${ }^{1}$ Mohammad Daud Ali, Hukum Islam, Pengantar Ilmu Hukum dan Tata Hukum Islam di Indonesia (Cet. XVII; Jakarta: PT. Raja Grafindo Persada, 2012), h. 61.

${ }^{2}$ Ahmad Rofiq, Hukum Perdata Islam di Indonesia (Cet. I; Jakarta: PT. Raja Grafindo Persada, 2013), h. 7.
} 
rukun dan syaratnya tidak boleh tertinggal, dalam arti perkawinan tidak sah bila keduanya tidak ada tau tidak lengkap. ${ }^{3}$

Hukum perkawinan dalam hal menempatkan mana yang rukun dan mana yang syarat terdapat perbedaan dikalangan ulama yang perbedaan ini tidak bersifat substansial. Perbedaan diantara pendapat tersebut disebabkan oleh karena berbeda dalam melihat fokus perkawinan itu. Semua ulama sepakat dalam hal-hal yang terlibat dan yang harus ada dalam suatu perkawinan adalah: akad perkawinan, lakilaki yang akan kawin, perempuan yang akan kawin, wali dari mempelai perempuan, saksi yang akan menyaksikan akad pernikahan dan mahar atau mas kawin.

Salah satu rukun dan syarat sahnya suatu perkawinan adalah adanya akad/ijab dan kabul. Ijab adalah ucapan "menikahkan" dari wali calon istri dan kabul adalah kata "penerimaan" dari calon suami. Ucapan ijab dan kabul dari kedua pihak harus terdengar jelas dihadapan majelis dan jelas terdengar oleh dua orang yang bertugas sebagai saksi nikah. Jadi sahnya perkawinan menurut hukum adalah diucapkannya ijab dari wali perempuan dan kabul dari calon suami pada saat yang sama didalam satu majelis akad nikah yang disaksikan oleh dua orang saksi yang sah. ${ }^{4}$

\section{METODE PENELITIAN}

Jenis penelitian ini tergolong kualitatif dengan menggunakan pendekatan penelitian pustaka (Library Research), yakni suatu peneltian dengan cara menuliskan, mengklarifikasi dan menjadikan data yang diperoleh dari berbagai sumber tertulis. Adapun metode pengumpulan data yakni mengguakan tehnik dokumen (studi pustaka), mengutip dan menganalisis data dengan tehnik dokumen dimaksudkan untuk mengumpulkan data terkait yang dimuat dalam dokumendokumen berupa buku-buku, jurnal dan hasil penelitian berupa skripsi, tesis, dan disertasi.

\section{HASIL \& PEMBAHASAN}

\section{A. Proses Perkawinan Menurut Hukum Islam}

1. Pengertian Perkawinan

Perkawinan dalam bahasa Indonesia berasal dari kata "kawin" yang berarti perjodohan laki-laki dan perempuan menjadi suami istri. ${ }^{5}$ Sedangkan menurut istilah ilmu fiqh dipakai perlakuan nikah yang berarti menghimpit, menindih, atau berkumpul. ${ }^{6}$ Menurut Ahmad Abu Zahrah bahwa : "Nikah adalah suatu akad yang dapat menghalalkan pergaulan antara seorang laki-laki dan seorang perempuan dan saling tolong menolong antara keduanya dengan dasar masing-masing mempunyai hak dan kewajiban". ${ }^{7}$

\footnotetext{
${ }^{3}$ Amir Syarifuddin, Hukum Perkawinan Islam di Indonesia (Cet. III; Jakarta: Kencana Prenda Media Group, 2009), h. 59.

${ }^{4}$ Hilman Hadikusuma, Hukum Perkawinan di Indonesia Menurut Perundangan, Hukum Adat dan Agama (Bandung: CV. Mandar Maju, 2007), h. 27.

${ }^{5}$ WJS. Poerwadarminto, Kamus Bahasa Indonesia (Cet. VIII; Jakarta: Balai Pustaka, 1985), h. 453.

${ }^{6}$ Kamal Markus, Asas-Asas Hukum Islam tentang Perkawinan (Jakarta: PT. Bulan Bintang, 1987), h. 1.

${ }^{7}$ Muhammad Abu Zahrah, Akhwalu Syaksiyah (Mesir Darul Fikri, Arabi, k.k), h. 19.
} 
Menurut Suyuti Talib menyebutkan bahwa perkawinan adalah perjanjian suci membentuk keluarga antara seorang laki-laki dan seorang perempuan. ${ }^{8}$ Sedangkan perkawinan menurut hukum Islam adalah pernikahan yaitu akad yang sangat kuat atau mitsaqan galizan untuk menaati perintah Allah dan melaksanakannya merupakan ibadah. ${ }^{9}$ Undang-undang perkawinan Nomor 1 Tahun 1974 pasal 1 tentang perkawinan merumuskan pengertian perkawinan ialah ikatan lahir batin antara seorang pria dan seorang wanita sebagai suami istri dengan tujuan membentuk keluarga (rumah tangga) yang bahagia dan kekal berdasarkan ketuhanan yang maha esa. ${ }^{10}$ Jadi, jika melihat pada pengertian yang diberikan oleh para ulama maupun berdasarkan undang-undang dapat disimpulkan bahwa perkawinan (nikah) adalah ikatan suci antara seorang laki-laki dan seorang perempuan untuk membangun rumah tangga (keluarga) yang sakinah, mawadah, marahmah dengan maksud tolong menolong dan menaati perintah Allah swt.

\section{Rukun dan Syarat Perkawinan}

Rukun yaitu sesuatu yang harus ada dan menentukan sah tidaknya suatu pekerjaan (ibadah) dan sesuatu itu termasuk dalam pekerjaan itu, seperti membasuh muka untuk wudhu' dan takbiratul ihram untuk sholat, ${ }^{11}$ atau calon pengantin lakilaki dan perempuan dalam perkawinan. Syarat adalah sesuatu yang mesti ada yang menentukan sah tidaknya suatu pekerjaan (ibadah), tetapi sesuatu itu tidak termasuk dalam rangkaian pekerjaan itu, seperti menutup aurat dalam sholat. ${ }^{12}$ Atau menurut Islam, calon laki-laki dan perempuan itu harus Islam. Menurut Husen memberi pengertian rukun dan syarat yaitu: "Rukun adalah sesuatu yang harus dipenuhi dan dilaksanakan termasuk bagian dari suatu perbuatan atau ibadah keagamaan. Syarat adalah sesuatu yang harus dipenuhi atau dilaksanakan sebelum suatu perbuatan atau ibadah dilaksanakan dan karenanya tidak termasuk bagian dari perbuatan atau ibadah tersebut" ${ }^{13}$

Dalam buku Hukum Fiqih Islam oleh M. Hasbi As-Shiddiqy dikemukakan bahwa rukun adalah sesuatu penegak yang dialah dapat berdiri sesuatu yang lain. Atau dapat dipandang adanya sesuatu dengan adanya. ${ }^{14}$ Sedangkan syarat adalah yang bersangkut hasil sesuatu kepadanya adanya. ${ }^{15}$ Jadi rukun dan syarat adalah sesuatu yang harus dipenuhi sebelum suatu kegiatan dilakukan, karena rukun dan syarat tersebut menentukan sah atau tidaknya suatu kegiatan ibadah.

a) Rukun Perkawinan

Menurut Imam Malik rukun nikah ada lima yaitu : wali, mas kawin, suami, istri, lafadh aqad. Sedangkan ulama Hanafiah berpendapat bahwa keduanya (antara ijab dan kabul itu). Didalam buku Asas-Asas Hukum Islam tentang perkawinan

\footnotetext{
${ }^{8}$ Suyuti Talib, Hukum Perkawinan di Indonesia (Cet. V; Jakarta: UI Press, 1986), h. 47.

${ }^{9}$ Undang-Undang R.I Nomor 1 Tahun 1974 tentang Perkawinan dan Kompilasi Hukum Isam (Cet. IV; Bandung: Citra Umbara, 2013), h. 324.

${ }^{10}$ Undang-Undang R.I Nomor 1 Tahun 1974 tentang Perkawinan dan Kompilasi Hukum Islam, h.2.

${ }^{11}$ Abdul Hamid Karim, Mahadi Awaliyah (Cet. I; Jakarta: Bulan Bintang, 1976), h. 9.

${ }^{12}$ Abdul Hamid Karim, Mahadi Awaliyah, h. 11.

${ }^{13}$ J.N.D Anderson M, Islamic Law the Modern World, diterjemahkan oleh Maenun Husain dengan judul Hukum Islam di Dunia Modern, Edisi I (Surabaya: Amapers, 1990), h. 47.

${ }^{14}$ T. M. Hasbi As-Siddhiqy, Hukum-Hukum Fiqh Islam (Cet. VII; Jakarta: Bulan Bintang, 1991), h. 647.

${ }^{15}$ T. M. Hasbi As-Siddhiqy, Hukum-Hukum Fiqh Islam h. 648.
} 
dikemukakan lima rukun perkawinan yaitu shigad akad, mas kawin, dua orang saksi, wali calon mempelai dan perwakilan. ${ }^{16}$

Rukun perkawinan dan termaktub dalam Kompilasi Hukum Islam di Indonesia adalah: a) calon suami; b) calon istri; c) wali nikah; d) dua orang saksi ; dan e) ijab dan qabul. ${ }^{17}$ Yang lima inilah yang biasanya di pakai dalam sebuah perkawinan di Indonesia.

b) Syarat Perkawinan

Syarat-Syarat perkawinan ialah syarat-syarat yang bertalian dengan rukunrukun perkawinan sebagaimana yang telah disebutkan di atas. Adapun syaratsyarat perkawinan adalah sebagai berkut:

1. Syarat-Syarat Suami

a. Beragama Islam

b. Bukan mahram dari calon istri

c. Tidak terpaksa atau kemauan sendiri

d. Orangnya tertentu/ jelas orangnya

e. Tidak sedang menjalankan ihram haji

2. Syarat-Syarat Istri

a. Beragama Islam

b. Tidak ada halangan syar'i yaitu tidak bersuami, bukan mahram atau dalam masa iddah.

c. Merdeka/atas kemauan sendiri

d. Jelas orangnya

e. Tidak sedang berihram haji

3. Syarat-Syarat Wali

a. Laki-laki

b. Baliqh

c. Waras akalnya

d. Adil

e. Tidak sedang irham haji 18

\section{B. Hukum Akad Nikah Melalui Via Telepon Perspektif Fiqh Kontenporer}

Perkawinan menurut agama Islam adalah perikatan antara wai perempuan (calon istri) dengan calon suami perempuan itu, bukan perikatan antara seorang pria dengan seorang wanita saja sebagaimana dimaksud dalam pasal 1 UU No. 1 Tahun 1974. ${ }^{19}$ Suatu perkawinan terdapat rukun dan syarat yang harus dipenuhi oleh kedua belah pihak yang akan melangsungkan perkawinan. Rukun dan syarat menentukan suatu perbuatan hukum terutama yang menyangkut dengan sah atau tidaknya perbuatan tersebut dari segi hukum. ${ }^{20}$ Salah satu rukun dalam suatu perkawinan adalah adanya akad nikah.

\footnotetext{
${ }^{16}$ Kamal Muchtar, Asas-Asas Hukum Islam tentang Perkawinan, (Cet. III; Jakarta: Bulan Bintang, 1993), h. 37.

${ }^{17}$ Abdurrahman, Kompilasi Hukum Islam (Cet. I; Jakarta: Akademi Pressindo, 1992), h. 116-117.

${ }^{18}$ Departemen Agama RI. Membina Keluarga Sakinah (Makassar, 2005), h. 17.

${ }^{19}$ Hilman Hadikusuma, Hukum Perkawinan di Indonesia menurut Perundangan, Hukum Adat dan Agama, h. 11 .

${ }^{20}$ Amir Syarifuddin, Hukum Perkawinan Islam di Indonesia, h. 59.
} 
Akad nikah adalah didasarkan atas suka sama suka, rela sama rela. Oleh karena perasaan rela sama rela itu adalah hal yang tersembunyi, maka sebagai manifestasinya adalah ijab dan kabul, oleh karena itu ijab dan kabul adalah unsur mendasar bagi keabsahan akad nikah. Ijab diucapkan oleh wali, sebagai pernyataan rela menyerahkan anak perempuannya kepada calon suami, sebagai pernyataan rela mempersunting calon istrinya. Lebih jauh lagi, ijab berarti menyerahkan amanah Allah kepada calon suami, dan kabul berarti sebagai lambang kerelaan menerima amanah Allah tersebut. Dengan ijab kabul menjadi halal sesuatu yang tadinya haram. ${ }^{21}$

Menurut Wahbah al-Zuhaili dalam kitabnya "Figh Islam wa Adillatuhu" menjelaskan kesepakatan para ulama tentang shigat akad (ijab dan qabul) disyaratkan 4 hal sebagai berikut:22

1. Kesesuaian dan ketetapan kalimat ijab dan qabul

2. Orang yang mengucapkan ijab dan qabul tidak boleh menarik kembali ucapannya.

3. Diselesaikan pada waktu akad

4. Dilakukan dalam satu majelis (ittihad al-Majelis)

Ulama berbeda dalam memahami apa yang dimaksud dengan ittihad al-majelis, diantara perbedaan itu ialah:

Pertama: yang dimaksud dengan ittihad al majelis ialah bahwa ijab dan kabul harus dilakukan dalam jarak waktu yang terdapat dalam satu upacara akad nikah, bukan dilakukan dalam jarak waktu terpisah, dalam arti ijab diucapkan dalm satu upacara, kemudian setelah upacara ijab bubar, kabul diucapkan pula pada acara berikutnya. Dalam hal yang disebutkan terakhir ini, meskipun dua acara berturutturut secara terpisah bisa jadi dilakukan dalam satu tempat yang sama, namun karena kesinambungan antara ijab dan kabul itu putus, maka pernikahan itu tidak sah. Dengan demikian, adanya keharusan satu majelis, adalah menyangkut kesatuan tempat. Karena, seperti dikemukakan diatas, meskipun tempatnya bersatu, tetapi apabila dilakukan dalam dua waktu, dalam dua acara terpisah, maka kesinambungan antara pelaksanaan ijab dan pelaksanaan kabul adalah tidak terwujud. Dan oleh karena itu akad nikahnya tidak sah. Satu contoh yang dijelaskan oleh al-Jaziri dalam memperjelas pengertian bersatu majelis dalam mazhab Hanafi adalah dalam masalah seorang laki-laki berkirim surat mengaqodkan nikah pada pihak perempuan yang dikehendakinya. Setelah surat itu sampai, lalu surat itu dibacakan didepan wali perempuan dan para saksi dalam majelis yang sama setelah isi surat dibacakan wali perempuan langsung mengucapkan penyerahannya (ijab). Praktik akad nikah seperti tersebut oleh kalangan Hanafiah dianggap sah, dengan alasan bahwa pembacaan qobul yang terdapat dalam surat calon suami dan pengucapan ijab dari pihak wanita, sama-sama di dengar oleh dua orang saksi dalam satu majelis yang sama bukan dalam dua upacara berturut-turut secara terpisah dari segi waktunya. Namun pengucapan akad nikah lebih dahulu diucapkan oleh calon suami baru kemudian diucapkan oleh wali perempuan.

\footnotetext{
${ }^{21}$ Satria Effendi, Problematika Hukum Keluarga Islam Kontemporer: Analisis Yurisprudensi dengan Pendekatan ushuliyah (Cet. III; Jakarta: Kencana Prenada Media Group, 2010), h. 2-3.

${ }^{22}$ Wahbah al-Zuhaili, Fiqh Islam wa Adillatuhu, h. 5.
} 
Mazhab Hanafi memahami bahwa ittihad al-Majelis adalah kesinambungan waktu (zaman) diantara ijab dan qobul bahkan kesatuan tempat (makan). Kisah yang dikemukakan oleh Ibnu Nujaim salah satu pihak yang berakad mengucapkan ijab disuatu tempat sedangkan pihak yang lain mengucapkan qobul ditempat yang lain pula, akadnya dianggap sah apabila pihak-pihak yang berakad dapat melihat mitranya dan suaranya dapat didengar dengan shahih meskipun keduanya terpisah jarak yang jauh.

Menurut mazhab Hambali diantara ijab dan qabul boleh ada waktu antara, tidak diucapkan pada saat yang sama, misalnya hari ini ijabnya dan kabulnya satu minggu kemudian. Asal saja akad nikah itu dilakukan dalam satu majelis dan tidak ada halangan yang sifatnya merupakan adanya keingkaran salah satu pihak untuk melakukan perkawinan itu. ${ }^{23}$

Dengan demikian, perkawinan yang dilakukan antara wali perempuan dikebayoran Jakarta dengan calon suami yang berada di Amerika Serikat menjadi perkawinan yang sah, apabila dilakukan ijab kabul dengan telepon dan dilakukan dengan saksi dua orang di dalam majelis akad nikah, apalagi yang mengucapkan ijab adalah bapak calon istri dan yang menerima (kabul) adalah calon suami. ${ }^{24}$ Pernikahan via telepon telah banyak terjadi dalam kehidupan masyarakat bahwa telah menjadi yurisprudensi sebagaimana Keputusan Pengadilan Agama Jakarta selatan No. 1751/P/1989, mengenai pengesahan akad nikah melalui via telepon. ${ }^{25}$

Dari keterangan diatas dapat dipahami bahwa masalah esensi dari persyaratan bersatu majelis adalah menyangkut masalah keharusan kesinambungan antara ijab dan kabul. Adanya persyaratan tidak boleh ada batas yang berarti antara ijab dan kabul dimaksudkan sebagai pendukung bahwa ijab dan kabul betul-betul sebagai manifestasi sebagai perasaan rela dari kedua belah pihak untuk mengadakan akad nikah.

Kedua, adalah pendapat yang mengatakan bahwa bersatu majelis diisyaratkan, bukan saja untuk menjamin kesinambungan antara ijab dan kabul, tetapi sangat erat hubungannya dengan tugas dua orang saksi, yang menurut pendapat ini harus dapat melihat dengat mata kepalanya bahwa ijab dan kabul betul-betul diucapkan oleh kedua orang yang melakukan akad. Dimaklumi bahwa keabsahan suatu redaksi dapat dipastikan dengan cara mendengarkannya. Akan tetapi, redaksi itu benar-benar asli diucapkan oleh kedua orang yang sedang melakukan akad, kepastiannya hanya dapat dijamin dengan jalan melihat para pihak yang melakukan pengucapan itu dengan mata kepala. Pendapat inilah yang dipegani (mu'tamad) di kalangan ulama-ulama mujtahid, terutama kalangan Syafi'iyah, sebagai konsekuensi pendapat ini kesaksian orang buta tidak dapat diterima untuk akad nikah. ${ }^{26}$

Dalam nukilan diatas dapat dipahami bahwa untuk keabsahan kesaksian akad nikah, ada satu target keyakinan yang harus diwujudkan oleh para saksi dalam kesaksiannya. Meskipun suatu redaksi dapat diketahui siapa pembicaranya dengan

\footnotetext{
${ }^{23}$ Mahmud Junus, Hukum Perkawinan dalam Islam (Jakarta: Pustaka Mahmudia, 1960), h. 15.

${ }^{24}$ Hilman Hadikusuma, Hukum Perkawinan di Indonesia Menurut Perundangan, Hukum Adat dan Agama, h. 28.

${ }^{25}$ Satria Effendi, Problematika Hukum Keluarga Islam Kontemprer: Analisis Yurisprudensi dengan Pendekatan Ushuliyah, h. 8.

${ }^{26}$ Satria Effendi, Problematika Hukum Keluarga Islam Kontemprer: Analisis Yurisprudensi dengan Pendekatan Ushuliyah, h. 6-7.
} 
jalan mendengarkan suara saja, namun bobotnya tidak akan sampai ketingkat keyakinan apabila dilihat pengungkapannya dengan mata kepala. Sedangkan dalam akad nikah, tingkat keyakinan yang disebutkan terakhir inilah yang diperlukan. Pandangan tersebut, sangat erat kaitannya dengan sikap para ulama terutama kalangan Syafi'iyah yang selalu bersikap hati-hati (ihtiyat) dalam menetapan suatu hukum, lebih-lebih lagi dalam masalah akad nikah, yang berfungsi sebagai penghalalan dari sesuatu yang tadinya diharamkan. Oleh karena itu kesaksian harus didasarkan atas pendengaran dan penglihatan, menurut pandangat ini ijab dan kabul melalui surat tanpa mewakilkan, tidak sah.

Mazhab Syafi'ih, Maliki dan Hambali, mengatakan salah satu syarat penting antara ijab dan qobul dalam satu tempat (makan) dan kurun waktu (zaman) yang sama adalah suatu keharusan esensi persyaratan ittihad al-Majelis adalah kesatuan tempat, bukan semata-mata kesatuan ucapan (kalam). Alasan kesegeraan dalam akad, artinya qobul harus dilakukan segera setelah ijab, secara langsung dan tidak terpisah oleh perkataan lain serta ijab dan qobul dilakukan dengan jelas dan shahih.

Karena itu pernikahan melalui telepon dan sebagainya menurut pendapat yang kedua, khususnya yang dipelopori oleh mazhab Syafi'i adalah tidak sah, karena selain terdapat kelemahan atau kekurangan dan keraguan dalam memenuhi rukunrukun nikah dan syarat-syaratnya sebagaimana diuraikan diatas, juga berdasarkan dalil-dalil syar'i sebagai berikut :

a. Nikah itu termasuk ibadah. Karena itu, pelaksanaan nikah harus sesuai dengan tuntunan Al-Qur'an dan sunah Nabi yang shahih, berdasarkan kaidah hukum :

Terjemahannya :

$$
\text { الا صل في العبادة حرام }
$$

"pada dasarnya ibadah itu haram."

Artinya, dalam masalah ibadah, manusia tidak boleh membuat-buat (merekayasa) aturan sendiri. Akad nikah mengandung arti ta"abbud. Oleh karena itu, pelaksanaannya harus terikat dengan apa yang telah di contohkan oleh Rasulullah saw., oleh karena itu akad nikah mengandung arti $t a^{\prime} a b b u d i$, pengembangan lewat analogi atau qiyas tidak dapat diterima dalam pelaksanaannya. ${ }^{27}$

b. Nikah merupakan peristiwa yang sangat penting dalam kehidupan manusia, dan itu bukanlah sembarang akad, tetapi merupakan akad yang mengandung sesuatu yang sakral dan syiar Islam serta tanggung jawab yang berat bagi suami istri, sebagaimana firman Allah dalam Q.S ar-Rum/30:21 yang berbunyi:

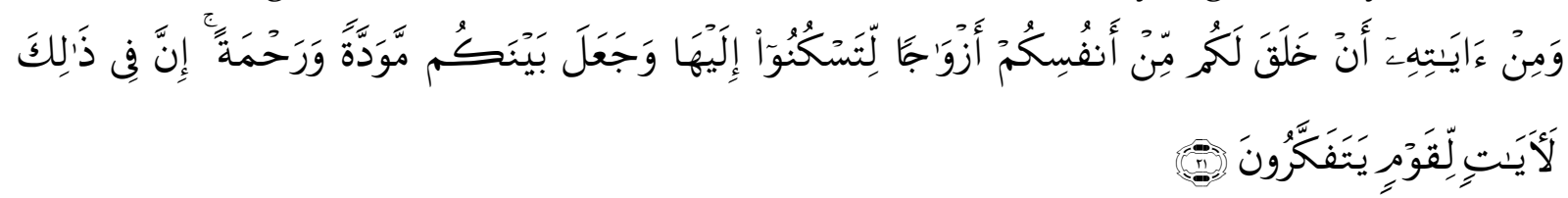

Terjemahannya:

\footnotetext{
${ }^{27}$ Satria Effendi, Problematika Hukum Keluarga Islam Kontemprer: Analisis Yurisprudensi dengan Pendekatan Ushuliyah, h. 8.
} 
Sebagian dari tanda keagungan Allah adalah Allah telah menciptakan istri-istri kalian dari jenis kalian sendiri agar kalian memperoleh ketenangan hidup bersamanya. Allah tanamkan kecintaan dan kasih sayang di antara kalian. Sungguh adanya hidup berpasangan suami istri menjadi bukti adanya kekuasaan Allah bagi orang-orang yang berakal. ${ }^{28}$

Nikah lewat telepon dan internet mengandung resiko tinggi berupa kemungkinan adanya penyalahgunaan atau penipuan (gharar atau khida'), dan dapat pula menimbulkan keraguan (cafused atau syak), apakah telah terpenuhi atau tidak rukun-rukun dan syarat-syarat nikahnya dengan baik. Salah satu syarat yang harus في مجلس و احدحضور() dipenuhi yaitu hadir dalam tempat yang sama

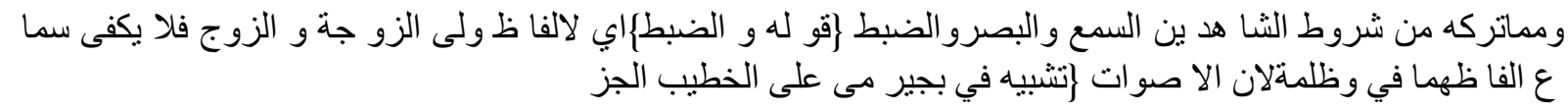

Terjemahannya :

Mendengar, melihat dan (dlobith) membenarkan adalah bagian dari syarat diperkenankannya dua orang saksi. (pernyataan penyusun 'wa al dlobthu) maksudnya lafadz (pengucapan) dari wali pengantin putri dan pengantin pria, maka tidaklah cukup mendengar lafadz (perkataan) mereka berdua dikegelapan, karena suara itu (mengandung) keserupaan. (Hasiyah AlBujairomi 'Ala al-Khottib juz 3, hal. 335) ${ }^{29}$

Dikhawatirkan jika akad dilaksanakan jarak jauh maka akan terjadi manipulasi. Misalnya suaranya di dubbing ataupun gambarnya dan backgroundnya tidak sesuai dengan kenyataan. Hal ini akan merugikan pihak perempuan. Karena perempuan harus dihormati, Islam mengajarkan itu.

Dampak negatif yang akan timbul juga akan lebih berbahaya lagi jika sudah punya anak. Hak waris ataupun hadlonahnya akan memberatkan dan juga membingungkan. ${ }^{30}$

Meskipun dengan dasar kehati-hatian dalam menetapkan suatu hukum apalagi yang berkaitam dengan proses menghalalkan sesuatu yang sebelumnya haram untuk menjadi halal lewat akad nikah, menurut penulis mazhab Syafi'i juga harus latar belakang terjadinya perkawinan via telepon dan semacamnya serta nilai kemaslahan yang timbul akibat pelaksanannya dan kemudaratan jika tidak melaksanakannya.

Baik pendapat yang pro terhadap pernikahan lewat telepon meupun yang kontra memiliki sisi kesamaan dan perbedaan. Persamaan dari pandangan tersebut terletak dari memahami bahwa suatu akad dalam perkawinan baik melalui via telepon/telekomperens maupun secara langsung menghadirkan kedua pasangan pengantin dalam satu majelis, mengharuskan adanya saksi sebagai rukun yang terpenuhi. Perbedaan mendasar tentang akad nikah via telepon/telekomperens,

\footnotetext{
${ }^{28}$ Kementerian Agama RI, Al-Qur'an dan Terjemahnya, h.506.

${ }^{29}$ Ahmad Masduqi Mahfud, Bahsul Masa'il, Tuhfatul Habib ala Syarhi al-Khatib (Ahhabul Royi PressHTTP://AHHABUL-ROYI.BLOGSPOT.COM), h. 335.

${ }^{30}$ Masjfuk Zuhdi, Masail Diniyah Ijma 'iyah (Jakarta: CV. Haji Masagung, 1994), h. 208-211.
} 
bagi yang menolak melakukan akad nikah via telepon adalah pada sikap kehatihatian, mengingat akad nikah adalah dalam rangka ta'abbudi (mendekatkan diri kepada Allah) serta menghindari hal-hal yang tidak diinginkan seperti penipuan, keraguan karena dibatasi oleh jarak/tempat. Sedangkan bagi ulama yang mendukung akad via telepon disamping sebagai respon atas realitas sosial juga upaya memberi kemaslahatan pada perkawinan tersebut.

\section{KESIMPULAN}

Perkawinan dalam Hukum Islam adalah sesuatu yang sakral dan tidak boleh dianggap main-main, sehingga memiliki aturan tetap sebagai pedoman dalam pelaksanaannya, syarat sahnya suatu perkawinan harus terpenuhinya semua rukunrukun yang telah di tetapkan oleh syari'at maupun Undang-undang Perkawinan maupun Kompilasi Hukum Islam (KHI).

Akad nikah via telepon adalah sesuatu yang baru bagi sebagian masyarakat Islam, meskipun menjadi sesuatu yang baru tapi prakteknya telah ada bahkan menjadi Yurisprudensi. Para ulama sepakat bahwa hal-hal yang berkaitan dengan syarat dan rukun perkawinan, yang menjadi perdebatan hanya pada pelaksanaan alittihad al majelis (bersatu dalam majelis), terlepas dari perbedaan itu akad nikah melalui telepon dapat dilakukan dengan syarat: 1) proses akad nikah berlangsung dalam satu waktu, 2) kesinambungan secara langsung antara ijab dan qobul dalam satu waktu akad nikah, 3) pelaku ijab qobul tidak diragukan (dipastikan keberadaannya), 4) ucapan/lafadz ijab dan qobul harus jelas (tidak samar-samar), 5) disaksikan oleh 2 orang saksi yang adil.

\section{IMPLIKASI}

Tulisan ini diharapkan dapat memberikan gambaran pada pembaca untuk memahami salah satu realitas sosial yang terjadi dalam kehidupan yaitu akad nikah via telepon/telekomprens adalah sesuatu hal yang baru, meskipun ulama memberikan ruang untuk pelaksanaannya meskipun dengan syarat tertentu. Namun setiap orang yang hendak menikah agar mempersiapkan segala sesuatunya terutama waktu pelaksanaan dan waktu kesibukan sehingga tidak ada yang yang dikorbankan dan pernikahanpun dapat berjalan dengan lancar.

\section{DAFTAR PUSTAKA}

Abdurrahman. Kompilasi Hukum Islam. Jakarta: Akademi Pressindo, 1992.

Ali, Mohmmad Daud. Hukum Islam, Pengantar Ilmu Hukum dan Tata Hukum Islam di Indonesia. Jakarta: PT. Raja Grafido Persada, 2012.

Departemen Agama RI. al-Qur'an dan Terjemahnya. Surabaya: Duta Ilmu, 2005.

Departemen Agama RI. Membina Keluarga Sakinah. Makasar, 2005.

Effendi, Satria. Problematika Hukum Keluarga Islam Kontemporer: Analisis Yurisprudensi dengan Pendekatan Ushuliyah. Jakarta: Kencana Prenada Media Group, 2010.

Hadikusuma, Hilman. Hukum Perkawinan di Indonesia menurut Perudangan, Hukum Adat dan Agama. Bandung: CV. Mandar Maju, 2007. 
Hasbi As-Siddhiqy, T. M. Hukum-Hukum Fiqh Islam. Jakarta: Pustaka Mahmudia, 1960.

Karim, Abdul Hamid. Mahadi Awaliyah. Jakarta: Bulan Bintang, 1976.

M, J.N.D Anderson. Islamic Law the Modern World, diterjemahkan oleh Maenun Husain dengan judul Hukum Islam di Dunia Modern. Surabaya: Amapers, 1990.

Markus, Kamal. Asas-Asas Hukum Islam tentang Perkawinan. Jakarta: PT. Bulan Bintang, 1987.

Muchtar, Kamal. Asas-Asas Hukum Islam tentang Perkawinan. Jakarta: Bulan Bintang, 1993.

Mahfud, Ahmad Masduqi. Bahsul Masa'il, Tuhfatul Habib ala Syarhi al-Khatib. Ahhabul Royi Press-HTTP:/ / AHHABUL-ROYI.BLOGSPOT.COM

Poerwadarminto, WJS. Kamus Bahasa Indonesia. Jakarta: Balai Pustaka, 1985.

Rasyid, Sulaiman. Figh Islam. Bandung: Sinar Baru Algensindo, 2012.

Rofiq, Ahmad. Hukum Perdata Islam di Indonesia. Jakarta: PT. Raja Grafindo Persada, 2013.

Syarifuddin, Amir. Hukum Perkawinan Islam di Indonesia. Jakarta: Kencana Prenda Media Group, 2009. 